Canadian Journal of Higher Education Revue canadienne d'enseignement supérieur

Volume 45, No. 1, 2015, pages 18 - 36

\title{
Transfers from College to One Ontario University: A Four-Year Outcome Study
}

Felice Martinello

Brock University

Jo Stewart

Yukon College

\begin{abstract}
In this follow-up study, college students who transferred to one Ontario university in 2008-2009 were compared to non-transfer students using several different measures of academic success at university. When compared to nontransfer students, college transfer students earned fewer credits each year, had lower GPAs, and were less able to earn credits from course attempts. The differences were small for students' first and second years but larger in years three and four. Despite the lower GPA, college transfer students were not more likely than non-transfer students to be eligible for academic suspension. College transfer students also attempted fewer courses and were much less likely to persist to Year 4. By spring 2012 (after four years of university), the college transfer students were more likely than non-transfer students to have graduated, but their degree of choice was a 15-credit three-year degree (as opposed to a 20-credit four-year honours or non-honours degree). Policy implications are discussed.
\end{abstract}

\section{Résumé}

Cette étude de suivi compare selon divers critères de réussite universitaire des étudiants d'une autre université qui se ont inscrits à une université ontarienne en 2008-2009 et des étudiants qui ne provenaient pas d'une autre université. Comparativement aux étudiants ne provenant pas d'une autre université, les étudiants qui en provenaient ont obtenu chaque année moins de crédits, ont obtenu une plus faible moyenne pondérée cumulative (MPC) et ont moins été en mesure d'obtenir des crédits dans les cours qu'ils ont entrepris. Les différences étaient minimes pour la première et la deuxième années, mais plus importantes pour les troisième et quatrième années. Malgré leur MPC 
inférieure, les étudiants provenant d'une autre université n'étaient pas plus susceptibles que les étudiants ne provenant pas d'une autre université d'être frappés d'une exclusion des cours. Ils s'inscrivaient également à moins de cours et tendaient beaucoup moins à persévérer jusqu'à la quatrième année. Au printemps 2012 (après quatre années d'études universitaires), les étudiants provenant d'une autre université étaient plus susceptibles d'obtenir leur diplôme que les étudiants ne provenant pas d'une autre université, mais ils avaient choisi plus souvent un programme de trois ans leur donnant 15 crédits qu'un programme de quatre ans, spécialisé ou non, leur donnant 20 crédits. L'article analyse les répercussions dans le domaine des politiques.

\section{Introduction}

Increasing the rate of student transfers from college to university has become a priority in Ontario in recent years (Kerr, McCloy, \& Liu, 2010; Ontario Ministry of Training, Colleges and Universities, 2011) and increasing numbers of Ontario postsecondary students have been transferring. (Association of Colleges of Applied Arts and Technology of Ontario, 2005; Embleton, 2008). However, little research has examined how the college students perform academically upon arriving at university (Stewart \& Martinello, 2012). Given the emphasis on increasing migration from college to university and supporting student success, as set out in the Ontario Ministry of Training, Colleges and University's Policy Statement for Ontario's Credit Transfer System (2011), it is vital that institutions understand what outcomes best define academic success amongst the population of transfer students, how to best measure those outcomes, how transfer students are faring according to those measures, and how to foster academic success in these students. In this study, the academic performance of students who transferred from a college to Brock University is tracked over four years and compared to non-transfer students. We compare students' persistence from year to year, their grades and eligibility for academic suspension, the numbers of credits attempted and completed, their rates of graduation, and the types of degrees received.

There is considerable research on the characteristics of transfer students in other Canadian jurisdictions. See, for example, Andres (1999, 2001), Andres, Qayyum, and Dawson (1997), Lambert-Maberly (2010), and Wattamaniuk (2010) for studies of British Columbia students. Other research, including studies of American students, has examined the academic consequences for transfer students, including studies on the reasons for transfer (Andres, 1999), perspectives and experiences of students (Andres, 2001), demographic characteristics of this group (Lee \& Frank, 1990; Wattamaniuk, 2010), transfer rates (Bers, 2007), the rate of attainment of a baccalaureate degree (Townsend, 2007), and grade point average (GPA) (Hills, 1965). Stewart and Martinello (2012) provide a short survey of some of this literature that points to the importance of studying how transfer students fare at universities in Canada. There is currently a paucity of Canadian research into the outcomes for transfer students, despite the number of students who are making the transfer every year. If Canadian research finds that transfer students are not succeeding, investigations into further or new supports for these students should proceed. If research finds that these Canadian students are succeeding government policies can be developed to encourage even higher rates of transfers. 
Research on transfer students in Ontario has been conducted from a variety of programs and perspectives (Bell, 1998; Craney, 2012; College University Consortium Council, 2007a, 2007b Menard, Liu, Zhang, \& Kielar, 2012; Stewart \& Martinello, 2012). Some found that college transfer students have lower retention and graduation rates than nontransfer students (Craney, 2012; Menard et al., 2012). Another reports that college transfer students are as successful as others when graduation is used to define success (Bell, 1998). Of particular note, two of these studies (Bell, 1998 and Craney, 2012) examined students enrolled at the same institution, yet the two studies had different findings. This difference may result from many factors, including different cohorts separated by roughly a dozen years or different variables studied. It would be interesting to do longitudinal research in order to investigate changes in student performance over time. One concern is that all of the few studies that have examined college-to-university transfer in Ontario have identified student success differently. This leads to difficulty interpreting the oftenconflicting results.

Stewart and Martinello (2012) used several different outcome measures to compare the performances of college transfer students, university transfer students, and nontransfer students in a sample of first-year courses at Brock University. When compared to students entering university from secondary school, Stewart and Martinello (2012) report that college transfer students perform no better or worse in terms of course grades and the likelihood of withdrawing from a course before completion. They also found that college transfer students who received failing grades in the first term of their course demonstrated better academic performance in their second term compared to the non-transfer students in the sample. There was also indirect evidence of a drop in GPA from college to university.

Stewart and Martinello (2012) examined transfer student performance in first-year courses in 2008-2009. The students in that sample have now had the opportunity for four years of study. The current study examines the performance of these students up to the end of the 2011-2012 academic year to determine whether college transfer students who began their studies at Brock University in 2008 have continued to succeed as well or better than non-transfer students. Specifically, the performance of college transfer students who took introductory-level social sciences courses at Brock University in 2008-2009 is compared to non-transfer students using several different outcome measures, including number of credits attempted and completed, grade point average, course withdrawals, and degree attainment after four years.

\section{Data}

The data consist of individual observations on 2,522 Brock undergraduate students. Of these, 155 students are transfers from community colleges who received transfer credit(s).

Brock University has a number of articulation agreements with colleges to help promote transfers but our data do not allow us to determine which students transferred under articulation agreements. The remaining 2,367 are non-transfer students who entered Brock from high school with no transfer credits from any postsecondary institution. The students are a subset of those examined in Stewart and Martinello (2012) so all were enrolled in at least one first-year social science course in the fall and winter terms of the 2008-2009 academic year. In this paper, however, transfer students from other universi- 
ties are excluded. This is done to keep the focus exclusively on college transfer students and to avoid reporting too many cases in the results section below. But the academic performance of students who transferred from other universities was investigated as part of a larger study, and the results are available from the authors. The sample is also restricted to only first-year Brock students. Only those students who had not enrolled in courses at Brock previously and had no Brock credits before 2008-2009 are included.

The original selection of students from first-year social science courses means that the sample is not representative of the student population at Brock. However, we do not believe this is a significant problem because the differences between the sample and the Brock student population are not large. For example, female students make up $63 \%$ of the sample while they comprised 59\% of the student population at Brock in the fall of 2008. Further, Brock students must take a first year social science course as part of their degree breadth requirements so the sample includes students from all faculties. Not surprisingly, the sample has higher proportions of students majoring in the social sciences (roughly $30 \%$ in the sample versus $25 \%$ for Brock as a whole) and in the humanities (roughly $16 \%$ in the sample versus 14\% for Brock as a whole). Conversely, Faculty of Business students are underrepresented in the sample (roughly $2 \%$ in the sample versus $15 \%$ for Brock), as are Faculty of Science students (roughly $3 \%$ in the sample versus $6 \%$ for Brock as a whole). Students with majors in applied health sciences make up $15 \%$ of the sample and $17 \%$ of the Brock student population. This suggests that the results are relevant for the overall student population at Brock and, reasonably, for other Canadian universities that are similar to Brock. The percentages of Brock students in the various faculties are calculated from the webpages of the Brock Office of Institutional Analysis (Brock University, 2012).

The data report several academic outcomes for each student: number of courses completed, withdrawals from courses, number of credits earned, grade averages, graduations, and major field of study for the fall to summer terms of 2008-2009, 2009-2010, and 2010-2011, and for the fall and winter terms of 2011-2012, which were the most recent data available at the time of writing. For the discussions that follow years $1,2,3$, and 4 refer to the 2008-2009, 2009-2010, 2010-2011, and 2011-2012 academic years described above, respectively, and not to the students' academic program years. All data were obtained from the registrar's record at Brock University.

In the analysis below, the number of observations in each sample declines in later academic years due to student attrition. The number of observations in each sample also varies from year to year because students are sometimes absent from Brock, and so they are excluded from the sample in that year. The absences occur mainly because of students' participation in exchange, co-op, or collaborative programs or because the student drops out for a year and then returns.

\section{Method}

Students' progress through their postsecondary programs is a complicated, multidimensional process with many different characteristics. This means that many different outcome measures can be used to compare the progress of students. Our approach is to examine several different measures of students' progress, one at a time, in separate subsections below. In every case the comparison is between college transfer students and non-transfer students. 
The basic method is to calculate the average or frequency of each measure of students' progress separately for college transfer and non-transfer students and then compare the two groups of students based on the measures. The hypothesis that there is no difference between transfer and non-transfer students (in the average value or frequency of the measure) is then tested. The $p$ values for the hypothesis tests are reported, and cases where the hypothesis is rejected at the $1 \%, 5 \%$, or $10 \%$ significance levels are identified.

The simple comparisons of performance measures reported below do not control for the effects of other student characteristics such as gender or major field of study. To address this, all of the comparisons between transfer and non-transfer students are repeated with regression analysis and controls for students' gender and major. The dummy variables representing students' major fields of study are often statistically significant in the regressions while gender, surprisingly, is usually not. Overall, however, regression analyses with controls for gender and major yield essentially the same results as the simple comparisons shown below. Thus, to save space, none of the regression estimate results are reported here, but they are available upon request. The discussions below comment on whether the regression analysis produced the same or slightly different results from those reported in the tables. Data on other student characteristics such as financial aid, family background, and socioeconomic status are not available in the registrar's data, so they could not be considered or developed for consideration in this study.

The following nomenclature is used to describe students' activity in their programs at Brock. If a student enrolls in a course and does not drop it before the end of the two-week add/drop registration period, then that course counts as an attempt. Students may withdraw from a course after the add/drop registration period, so not all course attempts are completed. Withdrawals from a course must occur before a specified date (usually the end of the eighth week of the term). If a student withdraws before this date, no final grade is assigned, and there is no academic penalty for the attempt. If the student does not withdraw from a course before the last withdrawal date then the course attempt is deemed to have been completed and a final grade is assigned, regardless of whether the student actually attended the course or wrote the final exam.

For completed course attempts, there are three possible outcomes: (a) a failed attempt where a failing final grade (less than 50\%) is assigned and the student does not earn the credit value of the course, (b) a repeated course attempt where a passing final grade $(50 \%$ or higher) is assigned but no credit is earned since the student had previously passed the course (e.g., the student repeated the course in an attempt to achieve a higher grade), and (c) a passed attempt where a passing final grade (50\% or higher) is assigned and the student earns the course credit.

The numbers of attempts and withdrawals, and the numbers of failed, repeated, and passed course attempts are all measured by the credit values of the courses involved. A typical full-time student with a full course load attempts five credits per year towards a three-year 15-credit pass degree or a four-year 20-credit degree.

\section{Results}

\section{Student Persistence or Attrition}

Persistence is defined by whether students attempt at least one course in an academic year, given that they persisted (attempted at least one course) in an earlier year. This 
means that persistence occurs regardless of what happens in their courses. Students may withdraw from the courses before completion, or complete the courses with or without earning the credits, and the enrolment still counts as persistence. The persistence measures are adjusted for graduations in either 2010 or 2011. If students have graduated they are not included in any of the subsequent years' measures of persistence.

The first three rows of Table 1 show one-year measures of persistence. They show the percentage of students who attempted at least one course in that year, given that they attempted at least one course in the previous year. The last two rows of Table 1 show three- and four-year measures of persistence starting from Year 1 (2008-2009). The penultimate row shows the percentage of students who attempted at least one course in Year 3 (2010-2011), given that they attempted at least one course in Year 1. The last row shows the same from Year 1 (2008-2009) to Year 4 (2011-2012).

Table 1

Students' Persistence: Percentage of Students Attempting Courses in the Later Year, Given an Attempt in the Earlier Year

\begin{tabular}{lccc}
\hline Years & Non-Transfer & College Transfer & $\begin{array}{c}p \text { value for the } \\
\text { difference }\end{array}$ \\
\hline Year 1 to Year 2 & $85.4[2,326]$ & $82.1[151]$ & 0.270 \\
Year 2 to Year 3 & $89.1[1,990]$ & $89.3[121]$ & 0.960 \\
Year 3 to Year 4 & $92.3[1,668]$ & $84.4^{\mathrm{b}}[77]$ & 0.013 \\
Year 1 to Year 3 & $77.2[2,325]$ & $74.3[148]$ & 0.420 \\
Year 1 to Year 4 & $71.1[2,196]$ & $56.5^{\mathrm{a}}[115]$ & 0.001 \\
\hline
\end{tabular}

Notes.

${ }^{\mathrm{a}},{ }^{\mathrm{b}},{ }^{\mathrm{c}}$ These figures show a statistically significant difference between transfer and non-transfer students at the $1 \%, 5 \%$ or $10 \%$ significance levels, respectively.

Square brackets show the number of observations in each sample.

The $p$ values for the hypothesis test of no difference between transfer and non-transfer student samples are shown. Chi-squared tests on $2 \times 2$ contingency tables of the occurrences (i.e., whether they attempted courses or not) are used for each test. Percentages, rather than frequencies, are shown because they are easier to interpret.

Compared to non-transfer students, college transfers are less likely to persist from Year 1 to Year 2 but the difference is small and statistically insignificant. College transfer and non-transfer students are virtually identical in their persistence from years 2 to 3. College transfer students, however, are much less likely to attempt courses in Year 4, given that they attempted courses in Year 3, and the difference is statistically significant. Again, persistence from Year 3 to Year 4 excludes all students who graduated at the end of years 2 or 3 .

The three- and four-year measures of persistence (reported in the last two rows of Table 1) show the same basic results. Persistence from Year 1 to Year 3 is lower for transfer students but not significantly different. Persistence from Year 1 to Year 4 is much lower for transfer students and the difference is statistically significant at very low probability levels. 
Probit regression analysis of persistence, with controls for students' gender and major field of study, show the same results for college transfer students compared to non-transfer students. Female students are estimated to have higher persistence, but the difference is not statistically significant. There are large and statistically significant differences in persistence across majors. Undeclared and general studies students have significantly lower persistence than students in other majors. This finding is not surprising, given that many researchers have reported a relationship between lower persistence rates and undeclared status (Graunke, Woosley, \& Helms, 2006; Leppel, 2001; Lewallen, 1993).

\section{Number of Credits Earned}

Table 2 reports the average number of credits earned by transfer and non-transfer students over various years and multiyear periods. The first four rows report the average number of credits earned in each of the first four years. Students are included only if they attempted at least one course in that year. The last three rows show the average sum of credits earned over the first two, first three, and all four academic years, respectively. For the multiyear averages, students had to have been enrolled continuously. This means that they had to have attempted at least one course in every year covered by the time period.

On average, college transfer students earn fewer credits in every year than non-transfer students and the differences are statistically significant. The differences in years 1 and 2 are only around a quarter of a credit. But college transfer students earn almost 0.7 fewer credits in Year 3, on average, and the difference grows to over one full credit in Year 4.

The regression analysis shows essentially the same statistically significant results after adjusting for gender and major, although the differences in credits earned are estimated to be smaller than those shown in Table 2.

Table 2

Average Number of Credits Earned, Given an Attempt in that Year or in Every Year for the Multiyear Periods

\begin{tabular}{lccc}
\hline Year & Non-Transfer & College Transfer & $\begin{array}{c}p \text { value for the } \\
\text { difference } \\
\text { using } t \text { tests }\end{array}$ \\
\hline Year 1: Fall 2008 to Summer 2009 & $4.13[2,326]$ & $3.87^{\mathrm{c}}[151]$ & 0.054 \\
Year 2: Fall 2009 to Summer 2010 & $4.26[1,992]$ & $4.03^{\mathrm{c}}[124]$ & 0.06o \\
Year 3: Fall 2010 to Summer 2011 & $4.40[1,798]$ & $3.72^{\mathrm{a}}[111]$ & 0.00O \\
Year 4: Fall 2011 to Winter 2012 & $4.16[1,573]$ & $3.08^{\mathrm{a}}[66]$ & 0.00O \\
Years 1 and 2: Fall 2008 to Summer 2010 & $8.70[1,987]$ & $8.29^{\mathrm{b}}[124]$ & 0.046 \\
Years 1 to 3: Fall 2008 to Summer 2011 & $13.5[1,772]$ & $12.20^{\mathrm{a}}[109]$ & 0.000 \\
Years 1 to 4: Fall 2008 to Winter 2012 & $18.0[1,532]$ & $14.40^{\mathrm{a}}[64]$ & 0.000 \\
\hline
\end{tabular}

Notes.

a , b, c These figures show a statistically significant difference between transfer and non-transfer students at the $1 \%, 5 \%$ or $10 \%$ significance levels, respectively.

Square brackets show the number of observations in each sample.

The $p$ values for the hypothesis test of no difference between means of the transfer and non-transfer student samples are shown. The $t$-tests allow different variances in each sample. 


\section{Average Grades and Eligibility for Academic Suspension}

The results above show clearly that transfer students earn fewer credits in each year than non-transfer students. This section and the next three sections explore the reasons why they earn fewer credits. In this section we compare the cumulative grade averages of each type of student since lower grades may result in fewer passed courses and fewer credits earned. We also examine whether transfer students are more likely to have average grades below $60 \%$ for two consecutive years, thereby making them eligible for academic suspension.

The first three rows of Table 3 show the average of students' cumulative grade averages in each year. Only students who completed at least one course in that year are included. College transfer students have lower cumulative grade averages in all years, compared to non-transfers, but the differences are not large and only the Year 3 difference is statistically significant. This result is also sensitive to the addition of controls for students' gender and major field of study. The differences between college transfer and non-transfer students' grade averages are estimated to be much smaller and statistically insignificant when those controls are added in the regression analysis.

If students' grades are low, they are put on probation. Low grades generally mean a grade average below $60 \%$, but there are other conditions and contingencies. If students continue to perform poorly while on probation then they are put on academic suspension. The last line of Table 3 shows rates of eligibility for academic suspension (based on average grades below $60 \%$ for two consecutive years) for transfer and non-transfer students. Despite their lower average grades, college transfer students are eligible for academic suspension at exactly the same rate as non-transfer students.

Table 3

Average of Students' Cumulative Grade Average and Eligibility for Suspension

\begin{tabular}{lccc}
\hline Year & Non-Transfer & College Transfer & $\begin{array}{c}p \text { value for the } \\
\text { difference }\end{array}$ \\
\hline Year 2 Average Grade: 2009-2010 & $68.5[1,967]$ & $67.4[123]$ & $0.19^{\dagger}$ \\
Year 3 Average Grade: 2010-2011 & $70.7[1,783]$ & $68.9^{\mathrm{b}}[111]$ & $0.03^{\dagger}$ \\
Year 4 Average Grade: 2011-2012 & $72.1[1,573]$ & $70.7[66]$ & $0.15^{\dagger}$ \\
$\begin{array}{l}\text { Percentage of students eligible for } \\
\quad \text { academic suspension }\end{array}$ & $10.3[2,367]$ & $10.3[155]$ & $0.98^{\ddagger}$ \\
\hline
\end{tabular}

Notes.

${ }^{\mathrm{b}}$ The difference between transfer and non-transfer students is statistically significant at the $5 \%$ level.

Square brackets show the number of observations in each sample.

The $p$ values for the hypothesis test of no difference between means of the transfer and non-transfer student samples are shown.

${ }^{+}$Calculated from $t$-tests, allowing different variances in each sample.

${ }^{*}$ Calculated from a Chi-squared test on a 2 x 2 contingency table of the occurrences (i.e., being eligible for suspension or not). 


\section{Converting Course Attempts into Academic Credits}

Differences in average grades do not appear to be large enough to explain why transfer students earn so many fewer credits in each year of their Brock programs. This section addresses the question of why transfer students earn fewer credits more directly by examining the rates at which students earn academic credits from their course attempts. Table 4 reports a credit attempt conversion rate that measures the percentage of attempts where the academic credit is received. Specifically, the attempt conversion rate equals the number of credits earned divided by the number of credits attempted over the time period (and multiplied by 100 to make it a percentage). The rate is less than 100\% (i.e., credits earned are less than the number of credit attempts) if students withdrew from courses before completion, received failing grades in their completed courses, or repeated courses that they had already passed.

Over Years 1 and 2, college transfer students were able to convert attempts (course enrolments) into credits at roughly the same rates as non-transfer students. In Year 1, college transfers were less successful, but the difference in the conversion rate is only 1.2 percentage points. In Year 2, college transfer students actually earned more credits from their attempts, but the difference is very small. In Year 3, and especially in Year 4, however, college transfer students were much less successful at converting course attempts into credits and the differences are statistically significant. The regression estimates show virtually the same results after controlling for gender and students' major field of study.

Table 4

Average Credit Attempt Conversion Rate: Percentage of the Academic Credits Attempted that Were Awarded

\begin{tabular}{lccc}
\hline Year & Non-Transfer & College Transfer & $\begin{array}{c}p \text { value for the } \\
\text { difference }\end{array}$ \\
\hline Year 1: Fall 2008 to Summer 2009 & $84.4[2,326]$ & $83.2[151]$ & 0.600 \\
Year 2: Fall 2009 to Summer 2010 & $86.6[1,992]$ & $87.1[124]$ & 0.810 \\
Year 3: Fall 2010 to Summer 2011 & $90.7[1,798]$ & $86.4^{\mathrm{c}}[111]$ & 0.098 \\
Year 4: Fall 2011 to Winter 2012 & $92.1[1,573]$ & $82.5^{\mathrm{b}}[66]$ & 0.018 \\
Years 1 and 2: Fall 2008 to Summer 2010 & $88.4[1,987]$ & $87.5[124]$ & 0.600 \\
Years 1 to 3: Fall 2008 to Summer 2011 & $91.5[1,772]$ & $89.1^{\mathrm{c}}[109]$ & 0.092 \\
Years 1 to 4: Fall 2008 to Winter 2012 & $93.1[1,532]$ & $89.1^{\mathrm{b}}[64]$ & 0.014 \\
\hline
\end{tabular}

Notes.

${ }^{\mathrm{a}},{ }^{\mathrm{b}},{ }^{\mathrm{c}}$ These figures show a statistically significant difference between transfer and non-transfer students at the $1 \%, 5 \%$ or $10 \%$ significance levels, respectively.

Square brackets show the number of observations in each sample.

The $p$ values for the hypothesis test of no difference between means of the transfer and non-transfer student samples are shown. They are calculated from $t$-tests, allowing different variances in each sample.

Further analysis investigated why college transfer students earned fewer credits from their attempts, but the detailed results are not shown in order to save space. The estimates show that college transfer students were more likely to withdraw from their course at- 
tempts before completion in all years. In Year 1, for example, non-transfer students withdrew from $6 \%$ of their course attempts while college transfers withdrew from $7.9 \%$, and the difference is statistically significant at the $10 \%$ level. The withdrawal rates are different from those reported in Stewart and Martinello (2012) because the sample of students is different and all 2008-2009 course withdrawals are considered here. The difference in withdrawal rates is much larger in Year 4, where non-transfer students withdrew from $4.2 \%$ of their course attempts while college transfers withdrew from over $10 \%$. In Years 2 and 3, college transfers also withdrew from more of their courses but the differences were small (less than two-thirds of a percentage point) and statistically insignificant. The higher withdrawal rates for college transfers are statistically significant if multiyear periods (e.g., years 1 and 2 , years 1 to 3 , or years 1 to 4 ) are considered.

The hypothesis tests for no difference in withdrawal rates between transfer and nontransfer students are adjusted for the fact that the majority of students do not withdraw from any of their courses in a given year, leaving a large mass point at zero in the distribution of withdrawal rates across students. Tobit regression analysis is used to make the adjustment for the mass point and similar results were obtained with and without the controls for gender and major.

We also examined the differences in outcomes when students did not withdraw and completed their courses. Specifically, we examined the rates at which students received failing grades in their courses or repeated courses that they had already passed. In either case, the students did not earn any credit even though the course was completed. The distributions of failed and repeated courses also have a large mass point at zero because the majority of students do not fail or repeat any courses in a year. Again, tobit regression analysis is used to adjust for the skewed distribution and controls for gender and major make little difference to the estimates. College transfer students were actually less likely than non-transfers to fail or repeat their completed courses in years 1 and 2 but the differences were small and far from being statistically significant. In years 3 and 4, however, transfer students were much more likely to have failed or repeated their completed courses and the differences were statistically significant.

Thus, the lower conversion rates of attempts into credits for college transfer students in years 3 and 4 are due to higher proportions of failed or repeated courses in those years. Higher withdrawal rates also contributed to the lower attempt conversion rates in Year 1 and year 4, but the biggest impact was in Year 4.

\section{Differences in Number of Attempts}

The differences in average grades and attempt success rates shown in the two previous subsections cannot explain fully why transfer students accumulate so many fewer credits in each year of their Brock programs. College transfer students were less successful at earning credits from their attempts in years 3 and 4, but the difference is not nearly large enough to explain the differences in total credits completed.

The main reason why transfer students completed fewer credits is that they attempted (enrolled in) substantially fewer courses in each year. Table 5 shows the number of credit attempts over the various years. Only students who attempted at least one course (i.e., were still attending Brock) in that year are included. Table 5 shows that college transfer students attempted fewer courses in each year, on average, and the differences are all 
statistically significant. The difference is particularly large in Year 4 with college transfers attempting 0.83 fewer credits than non-transfer students. Regression estimates show virtually the same results after controlling for gender and students' major field of study.

It is important to consider whether the smaller number of attempts shown in Table 5 is due solely to a larger proportion of part-time students among college transfers. According to this scenario, full-time college transfer students attempt the same number of credits as full-time non-transfer students, and part-time college transfer students attempt the same number of credits as part-time non-transfer students. But college transfer students are more likely to be part-time students, which makes the overall average number of attempts (shown in Table 5) lower for college transfer students. Figure 1 shows that this composition effect (more part-time students) does not account for the differences shown in Table 5 .

Table 5

Average Number of Course Attempts

\begin{tabular}{lccc}
\hline Year & Non-Transfer & College Transfer & $\begin{array}{c}p \text { value for the } \\
\text { difference using t tests }\end{array}$ \\
\hline Year 1: 2008-2009 & $4.86[2,326]$ & $4.63^{\mathrm{b}}[151]$ & 0.011 \\
Year 2: 2009-2010 & $4.84[1,992]$ & $4.63^{\mathrm{b}}[124]$ & 0.017 \\
Year 3: 2010-2011 & $4.77[1,798]$ & $4.18^{\mathrm{a}}[111]$ & 0.000 \\
Year 4: 2011-2012 & $4.46[1,573]$ & $3.63^{\mathrm{a}}[66]$ & 0.000 \\
\hline
\end{tabular}

Notes.

a , b, c These figures show a statistically significant difference between transfer and non-transfer students at the $1 \%, 5 \%$ or $10 \%$ significance levels, respectively.

Square brackets show the number of observations in each sample.

The $p$ values for the hypothesis test of no difference between means of the transfer and non-transfer student

samples are shown. The t-tests allow different variances in each sample.

Figure 1 shows the distribution of credit attempts for transfer and non-transfer students in every year. Note that the scales showing the percentage of students with each number of attempts (the "y axes") vary from year to year, but they are the same for transfer and non-transfer students in a given year. Students who attempted more than seven credits worth of courses are omitted from Figure 1 to keep the horizontal axis scales manageable. It is not difficult to attempt more than seven credits because the first three years include the spring and summer terms and withdrawals from courses count as attempts. But only a few students attempt more than seven credits in any year so the truncation does not affect the results.

Figure 1 shows that attempting five credits was the dominant choice for non-transfer students in every year. College transfers, however, were much less likely to attempt five credits and much more likely to attempt 3 to 4.5 credits. So the lower average number of attempts by college transfers was not due solely to a higher proportion of part-time students attempting just 1 or 2 credits per year. Figure 1 shows that college transfers did have higher proportions of part-time students (i.e., students attempting just one or two credits), especially in years 1,3 , and 4 . But the bigger difference is the much higher proportion of college transfer students attempting 3 to 4.5 credits, rather than the five credits attempted by non-transfer students. 


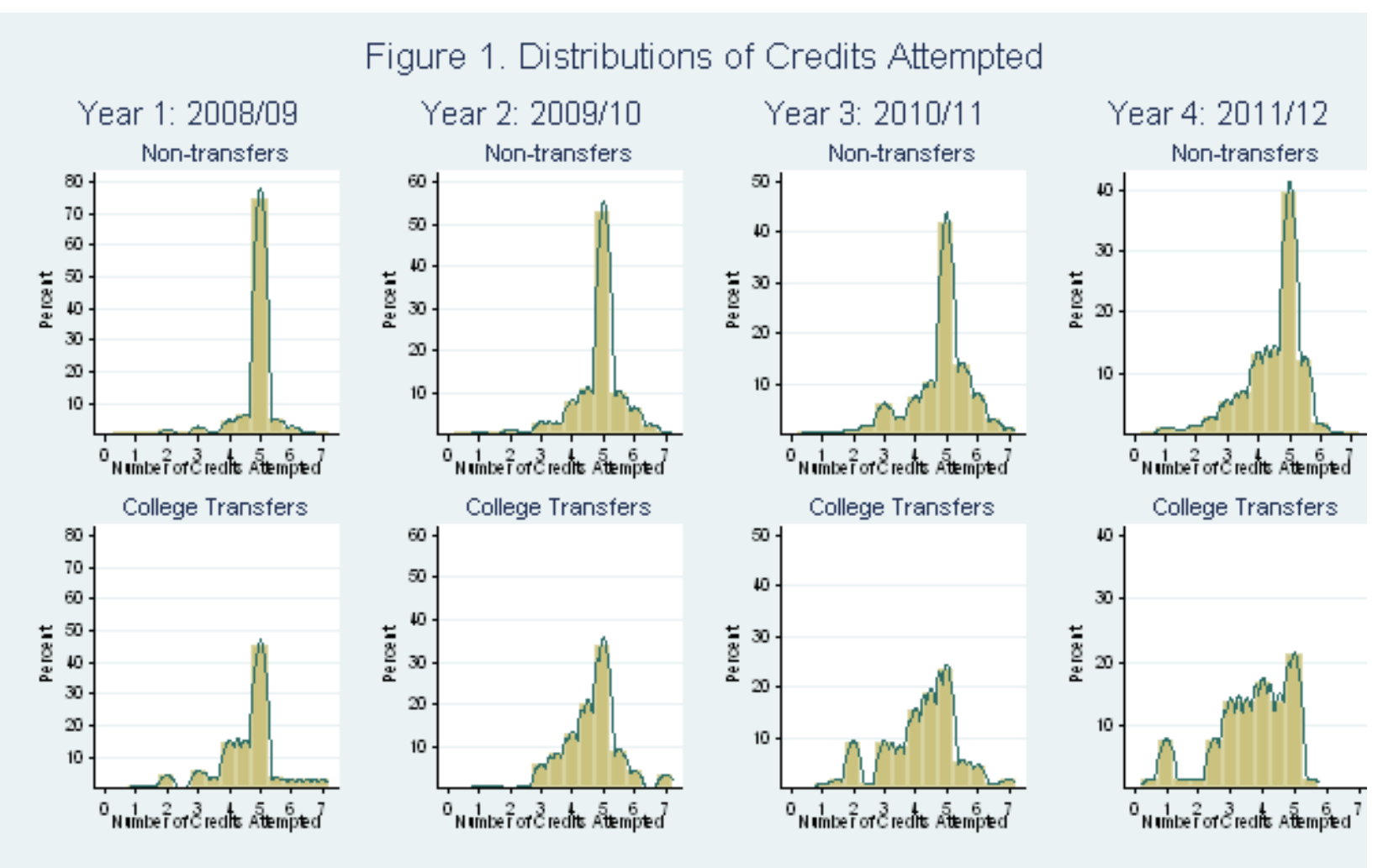

\section{Total Number of Credits Earned, Including Transfer Credits}

Transfer students may attempt and earn fewer credits in each year because they know that they do not have to earn as many credits as non-transfer students; they already have their transfer credits when they start their Brock programs. If transfer students plan to graduate after three or four years, as non-transfer students typically plan to do (but usually do not-see below), then they do not have to complete as many Brock credits in each year as non-transfer students.

Figure 2 shows the average total number of credits held after each year, including transfer credits, for students who attempted courses in each of the preceding years. The shaded areas shows 95\% confidence intervals for the average total number of credits.

On average, college transfer students were awarded 2.7 transfer credits before the start of the 2008-2009 academic year and this difference in starting points is shown in Figure 2. But the difference in the total number of credits narrows each year as transfer students accumulate fewer credits in each year. The gap narrows most quickly in Year 4. By the end of the winter term of Year 4, college transfer students who attempted courses in Year 4 held virtually the same total number of credits (on average and including transfer credits) as non-transfer students.

\section{Differences in Graduation}

Given that transfer students reach 15 credits before non-transfer students, do they graduate sooner than non-transfer students? Do they graduate with similar degrees?

Table 6 shows the percentages of students who graduated within three years or less (i.e., in 2010 or 2011) and within four years (i.e., by the spring convocation of 2012-the 
latest data available). College transfer students are much more likely to graduate before non-transfer students and all of the differences are statistically significant. Fewer than 5\% of non-transfer students graduate within three years of their start at Brock, while almost a quarter of college transfers graduate within three years. The difference between transfer and non-transfer students is smaller for graduation by spring of their fourth year, but the basic result is unchanged. Transfer students are more likely to have graduated by spring of 2012. Probit regression estimates show virtually the identical results for graduations after controlling for gender and major field of study.

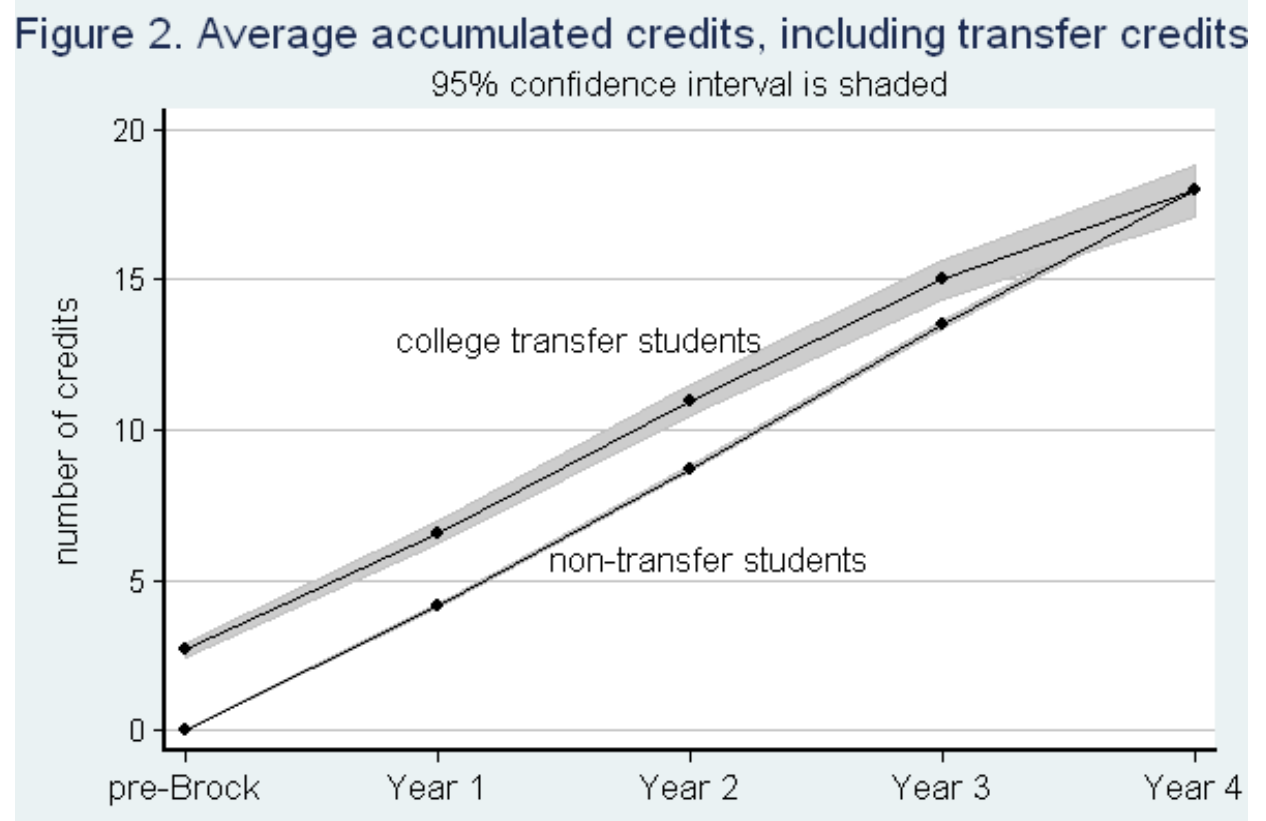

Table 6

Percentage of Students Graduating Within Three Years and Within Four Years

\begin{tabular}{lccc}
\hline Years to Graduation & $\begin{array}{c}\text { Percentage Non- } \\
\text { Transfer }\end{array}$ & $\begin{array}{c}\text { Percentage College } \\
\text { Transfer }\end{array}$ & $\begin{array}{c}p \text { value for the } \\
\text { difference }\end{array}$ \\
\hline $\begin{array}{l}\text { Percentages graduating in three years } \\
\text { or less (i.e., in 2010 or 2011) }\end{array}$ & $4.31[2,367]$ & $23.20^{\mathrm{a}}[155]$ & 0.00 \\
$\begin{array}{l}\text { Percentages graduating within four } \\
\text { years (i.e., by spring 2012 convocation) }\end{array}$ & $35.60[2,367]$ & $45.81^{\mathrm{a}}[155]$ & 0.01 \\
\hline
\end{tabular}

Notes.

${ }^{a}$ The difference between transfer and non-transfer students is statistically significant at the $1 \%$ level.

Square brackets show the number of observations in each sample.

The $p$ values for the hypothesis test of no difference between transfer and non-transfer student samples are shown. Chi-squared tests on 2 x 2 contingency tables of the occurrences (i.e., whether they graduated or not) are used for each test. Percentages, rather than frequencies, are shown because they are easier to interpret. 
Brock's degrees can be classified into three types: (a) three-year pass degrees requiring 15 credits with at least a $60 \%$ grade average, among other requirements, (b) fouryear, non-honours or major degrees requiring 20 credits with at least a $60 \%$ grade average, among other requirements, and (c) honours degrees requiring 20 credits with a 70\% grade average over credits in their major and a 60\% average over other courses, among other requirements.

Table 7 shows the percentage of graduands receiving each type of degree over the four years. Only the highest degree received is considered because a few students graduated with pass degrees in 2011 and then upgraded and graduated with major or honours degrees in 2012. In this case, the hypothesis test checks whether the relative frequencies of the three different outcomes-graduating with a pass, or major or honours degree-are the same for transfer and non-transfer students. Table 7 shows that, among students who graduated on or before the spring of 2012, transfer students are much more likely to have graduated with a pass degree and much less likely to have graduated with an honours degree. The differences are statistically significant.

Table 7.

Highest Degree Awarded, as a Percentage of the Total Number of Graduands

\begin{tabular}{lcc}
\hline Degrees & Non-Transfer & College Transfer \\
\hline Pass degree & 30.8 & 50.7 \\
Major degree & 8.9 & 7.0 \\
Honours degree & 60.3 & 42.3 \\
Number of observations & {$[842]$} & {$[71]$} \\
$\begin{array}{l}p \text { value for whether transfer students have the } \\
\text { same relative frequencies }\end{array}$ & & $0.003^{\mathrm{a}}$ \\
\hline
\end{tabular}

Notes.

${ }^{a}$ The difference between transfer and non-transfer students is statistically significant at the $1 \%$ level. The $\mathrm{p}$ value for the hypothesis test of no difference between transfer and non-transfer student samples is shown. A Chi-squared test on a 3 x 2 contingency table of the occurrences (i.e., the number graduating with each type of degree) is used.

\section{Discussion}

A data set showing Brock students' course attempts, withdrawals, academic credits, grades, graduations, and other outcomes from the fall term of 2008-2009 to the winter term of 2011-2012 was collected. All of the students started their first year of study at Brock in the fall term of 2008. The data were used to compare the progress of students who transferred from community colleges to the progress of non-transfer students in their Brock programs. There is an inherent limitation with this study design in that only data from one university in the province were examined. Given the relative lack of research into the experience of college transfer students in Ontario, this should be seen as a call to other institutions in the province to complete similar research in order to discover whether the results are generalizable to other transfer students in the province. 
The biggest difference between transfer and non-transfer students is that transfer students enrolled in (attempted) fewer courses in every year. The differences are especially large in the third and fourth years of study. The smaller number of attempts is the most important reason why transfer students earned fewer academic credits in each year. In the third and fourth years of their studies at Brock, transfer students earned 0.68 and 1.08 fewer academic credits, on average, compared to non-transfer students.

Of course transfer students also had their transfer credits, in addition to the Brock credits that they earned. The transfer credits more than offset the smaller number of Brock credits earned over the first three years at Brock, but the total numbers of credits held are virtually equal by the end of the fourth year. Transfer students use the additional credits to graduate earlier than non-transfer students, on average. Transfer students also graduate with lower level degrees, which also help them to graduate earlier. Among students who graduated in or before the spring 2012, college transfers were much more likely to be awarded 15-credit pass degrees rather than 20-credit honours or non-honours degrees.

In general, the performance of college transfer students was similar to that of nontransfer students over the first two years of their studies at Brock. College transfer students were not significantly different from non-transfers in their persistence to the start of Year 3, second-year grades, and ability to earn academic credits from their course attempts in years 1 and 2. In their third and fourth years, however, college transfer students showed significantly poorer achievement in their programs. They were much less likely to persist to Year 4, even after adjusting for their earlier graduations, and they were much less able to earn academic credits from their course attempts. Their lower success rates in course attempts were due to both a greater propensity to withdraw from courses before completion (especially in Year 4) and from more failed and repeated courses.

College transfer students had to have spent at least two years completing a college credential so they are almost certainly older, on average, than non-transfer students. Other researchers have reported other key socioeconomic differences between college transfer and non-transfer students. These include higher proportions of students from lower income families and with disabilities. College transfers are also more likely to be Aboriginal and first-generation students (Kerr et al., 2010). These differences may account for the poorer performance of college transfer students in their later years. Competing demands on students may be the cause of the weaker performance as students move through their programs, especially because the later years of degree programs tend to be more challenging. This may also account for the fact that college transfer students were more likely to graduate with a 15-credit three-year degree as opposed to a 20-credit four-year degree. They may not have had the socioeconomic resources to continue in what would be a fifth, sixth, or even seventh year of postsecondary studies for them.

The rates of eligibility for academic suspension, cumulative grade averages, and graduation rates with pass degrees all suggest that college transfer students are, in general, capable of completing a university degree in good time. This is important information to consider when determining whether college students should be encouraged to transfer to university. The evidence suggests that they can, in fact, be encouraged because those who have transferred have been able to succeed in university courses and graduate. Transfer students had less success in years 3 and 4 relative to non-transfer students, but their absolute level of performance appears sufficient to allow them to accumulate sufficient 
credits and grades for graduation. This conclusion is tentative, however, until more information on graduation rates can be collected after another year or two. While seemingly able to complete undergraduate degrees, transfer students' poorer performance in years 3 and 4 suggests that they will have less opportunity to enroll in competitive graduate or professional programs after graduation.

An important caveat is that the evidence suffers from a self-selection problem. All of the transfer students in the sample voluntarily chose to transfer, so they may have systematically different characteristics (possibly unobservable) from other college students whose academic records would also make them eligible for a transfer to university. Estimating the impact of the self-selection of transfers on the results is an important topic for future work. Another caveat, also noted above, is that insufficient time has passed to make conclusive comparisons between the graduation rates of transfer and non-transfer students.

As for support for college transfer students, it is notable that academic support programs in universities are mostly focused on first- and second-year students, the years when college transfer students do not appear to require more help compared to nontransfer students. There are very few academic support programs targeted at third and fourth year students, which is when college transfer students have poorer academic results and require more help. Further investigation needs to be made into the specific types of supports that college transfer students might need in order to effectively complete their upper-year courses. These could range from socioeconomic and family support for those from lower income households, to intrusive academic advising (transfer students had typical academic success in years 1 and 2 so they may delay too long before seeking academic advice), to developing learning-skills programs with more emphasis on higher level academic skills rather than high school remediation, to providing more support for students with disabilities and first-generation students. The supports would provide the tools that transfer students require to successfully complete senior level courses and earn higher level degrees more efficiently than shown in this data set. Socioeconomic and family support would provide financial resources, while advising and learning-skills support would provide them with the program knowledge and academic skills base needed to efficiently complete more credits each year. If college transfer students were to receive these supports, especially in their upper years, they may find it easier to complete more courses each year and higher level degrees. In turn, this would allow more college transfer students to have access to graduate and professional programs.

Similar research also needs to be done across more institutions, programs, and contexts to examine how outcomes differ across different situations. For example, students in programs where more or fewer courses per year are required or are usually completed may experience different outcomes. Students in dedicated major programs may show differences from students who are "undeclared" or in more general learning programs. Transfer students from lower socioeconomic strata may show different patterns of success than students who are not struggling with external financial pressures. Research could also allow for more direct questioning of transfer students to understand their motivations and academic goals before tracking their overall experiences and outcomes. It is not until further research can be done that these other questions will be answered. Answering these questions will help guide the development of supports offered to transfer students to increase the likelihood that they will succeed at university. 
From a policy perspective, it is important to consider some of the outcomes reported above when developing initiatives that encourage transfers from college to university. In recent years, much attention has been paid to the policy of developing transfer pathways for students in order to increase the rate of transfer for college students (see for example, Ontario Ministry of Training, Colleges and Universities, 2011). The results reported here provide some support for these policies. College transfer students are able to complete university programs and earn degrees thereby improving education levels in the workforce and increasing their career options and future earnings. The support for more transfers, however, is not unqualified. First, the transfer students considered here have poorer academic outcomes than non-transfer students in their third and fourth years and appear less likely to graduate with higher level undergraduate degrees. Both make transfer students less eligible for further graduate-level studies or professional programs. Second, there is the data self-selection caveat. If transfer rates from college to university are increased, the additional students may be systematically different from the transfer students examined here, leading to different outcomes for them.

As for university and government policies to support college transfer students, we speculate that the lower likelihood of progressing to fourth year and the weaker performance in upper years may be due to exhaustion of the financial and family resources required to support the extra years of education and resulting delay of earnings and career progress. This seems all the more likely given the generally less advantaged status of transfer students documented in the literature (Lee \& Frank, 1990; Wattamaniuk, 2010). It follows that improved family, social, and financial support would increase the rate of transfers, their academic performance, and the level of education achieved at university. Finally, the results strongly suggest that transfer students require more academic and administrative support focused on their upper years in addition to any supports that already exist in their first and second years following the transition from college. This additional support could include proactive advising and skills development focused on upper year rather than introductory course level skills and course management. This is where the transfer students in our sample lag behind non-transfer students and where there is the biggest opportunity to improve their levels of academic achievement.

\section{References}

Andres, L. (1999). Investigating transfer: The student's perspective. Research Report. British Columbia Council on Admission and Transfer. Retreived from www.bccat.bc.ca/ pubs/rr-jul99.pdf

Andres, L. (2001). Transfer from community college to university: Perspectives and experiences of British Columbia students. The Canadian Journal of Higher Education, 31(1), 35-74.

Andres, L., Qayyum, A., \& Dawson, J. (1997). Investigating transfer project phase I: Transfer experiences of students from community college to university. Vancouver, BC: UBC Centre for Policy Studies in Education. Retreived from www.bccat.bc.ca/pubs/itp1.pdf

Association of Colleges of Applied Arts and Technology of Ontario. (2005). Student mobility within Ontario's postsecondary sector. Retreived from http://www.ontransfer. ca/www/files_docs/content/pdf/en/oncat_research_reports/oncat_research_ reports_13.pdf 
Bell, S. (1998). College transfer students: A Canadian case. Community College Journal of Research and Practice, 22(1). Retreived from http://web.ebscohost.com/ ehost $/$ detail ?vid=3\&hid $=18 \&$ sid $=789067 \mathrm{c} 4-5$ e96-4ae6-ba2a-2fc85337eb5d\%40session mgr14\&bdata=JnNpdGU9ZWhvc3QtbGl2ZSZzY29wZT1zaXRl \#db=aph\&AN=493762

Bers, T.H. (2007) Advancing research on the community college. Community College Review, 43(3), 170-183.

Brock University. (2012). Institutional Analysis and Planning, Financial and Administrative Services. Retreived from http://www.brocku.ca/finance/faculty-andstaff/institutional-analysis/reports/2012-13/Fall_Enrolment_2012

College University Consortium Council. (2007a). An analysis of undergraduate students admitted to York University from an Ontario college of applied arts and technology (CAAT) between 1996 and 2006. Retreived from http://www.oncat.ca/files_ docs/content/pdf/en/oncat_research_reports/oncat_research_reports_16.pdf

College University Consortium Council. (2007b). Measuring the success of college transfer success at Nipissing University, 1994-2005. Retreived from http://www.oncat. ca/files_docs/content/pdf/en/oncat_research_reports/oncat_research_reports_17.pdf

Craney, G. (2012). College credit transfer \& collaboration at York University. Paper presented at the Student Pathways in Higher Education Conference, Toronto, ON.

Embleton, S. (2008). A decade of history: Comparing Ontario secondary and college (CAAT) transfer students at York University. Paper presented at the Pan-Canadian Conference on Articulation and Transfer Conference, Toronto, ON.

Graunke, S. S., Woosley, S. A., \& Helms, L. L. (2006). How do their initial goals impact students' chances to graduate? An exploration of three types of commitment. NACADA Journal, 26(1), 13-18.

Hills, J. (1965). Transfer shock: The academic performance of the junior college transfer student. The Journal of Experimental Education, 33(3), 201-215.

Kerr, A., McCloy, U., Liu, S. (2010). Forging pathways: Students who transfer between Ontario colleges and universities. Toronto, ON: Higher Education Quality Council of Ontario. Retreived from http://books2.scholarsportal.info/viewdoc.html?id=/ebooks/ ebookso/gibson_cppc/2011-03-23/1/10443684\#

Lambert-Maberly, A. (2010). Profile of BC college transfer students 2003/4 to 2007/8. British Columbia Council on Admission and Transfer. Retreived from www.bccat.bc.ca/ pubs/rr_apr10.pdf

Lee, V. E., \& Frank, K. A. (1990). Students' characteristics that facilitate the transfer from two-year to four-year colleges. Sociology of Education, 63(3), 178-193.

Leppel, K. (2001). The impact of major on college persistence among freshmen. Higher Education, 41(3), 327-342.

Lewallen, W. (1993). The impact of being "undecided" on college-student persistence. Journal of College Student Development, 34(2), 103-113. 
Menard, K., Liu, Y., Zhang, J., Kielar, M. (2012). A longitudinal analysis of the college transfer pathway at McMaster. Paper presented at the Student Pathways in Higher Education Conference, Toronto, ON.

Ontario Ministry of Training, Colleges and Universities. (2011). Policy statement for Ontario's credit transfer system. Retreived from www.tcu.gov.on.ca/eng/eopg/ publications/CreditTransferE.pdf

Stewart, J. \& Martinello, F. (2012). Are transfer students different? An examination of first year grades and course withdrawals. Canadian Journal of Higher Education, 42(1). $1-24$.

Townsend, B. K. (2007). Interpreting the influence of community college attendance upon baccalaureate attainment. Community College Review, 35(2), 128-136.

Wattamaniuk, W. J. (2010). Trends in the flows of transfer students from BC public colleges, institutes, and teaching intensive universities to $\mathrm{BC}$ public research universities. British Columbia Council on Admission and Transfer. Retreived from www.bccat.bc.ca/ pubs/transfertrendsanalysis.pdf

\section{Acknowledgments}

We would like to thank Melissa Dol for her valuable assistance with data collection. We also thank the Brock University registrar's office for permission and help with the data. Financial support from ONTransfer is gratefully acknowledged, but the opinions expressed are those of the authors and not ONTransfer.

\section{Contact Information}

Jo Stewart

Associate Registrar

Yukon College

jstewart@yukoncollege.yk.ca

Felice Martinello is currently a professor of economics at Brock University in St. Catharines, Ontario. His earlier work examined labour unions, with publications on wage determination in heavily unionized industries, union organizing activity, and stock market responses to union certification drives. His more recent work has focused on postsecondary education. It includes studies of faculty salaries, students' transitions across postsecondary programs and different types of institutions, decreases in students' grades from high school to university, and the effect of withdrawal dates on students' persistence.

Having completed her education at Brock University and the University of Waterloo, Jo Stewart has a long-standing interest in student success and retention. She has published articles about academic advising and university-college transfers. Prior to becoming the Associate Registrar at Yukon College, Jo was involved in developing university-college transfer programs for a variety of disciplines in the social sciences. Jo has recently taken her interest in transfer student success to Yukon College where she plans to continue her studies of how well students succeed upon transfer to college programs. 